\title{
Underemployment/Unemployment and the Public Placebo of Educational Failure
}

\author{
Steven Gerardi \\ New York City College of Technology, New York, USA \\ Email: SGerardi@Citytech.Cuny.Edu
}

Received June $17^{\text {th }}$, 2013; revised July $24^{\text {th }}$, 2013; accepted August $9^{\text {th }}, 2013$

\begin{abstract}
Copyright (c) 2013 Steven Gerardi. This is an open access article distributed under the Creative Commons Attribution License, which permits unrestricted use, distribution, and reproduction in any medium, provided the original work is properly cited.
\end{abstract}

\begin{abstract}
Over the last several decades there has been a series of national economic/trade policies which has had a negative impact on employment, the middle class, organized labor, upward mobility, and the American Dream. This effort suggests that in order to compensate for economic/trade decisions which has led to a tremendous loss of all forms of employment in the USA, the power elite (both economic and political) have used the myth that the American Educational system has failed to educate, hence creating a skill gap and unemployment/underemployment.
\end{abstract}

Keywords: Educational Failure Myth and the Skills Gap

\section{Introduction}

According to the current social and political paradigms, the major cause of the loss of millions of jobs in the USA has been the failure of the American educational system to educate a skilled workforce. Hence, often we are exposed to comments made by Apple Corporation's Mr. Tim Cook, who suggested that the reason the company has moved its manufacturing plants to China was not to access cheap labor, rather Apple's inability to employ a skilled workforce in the USA, specifically Engineers (the company in 2012 has been charged with worker abuse in the Foxconn plant. A January 2013 report indicated that FoxxCom has used underage child labor and inappropriate labeling it "Student internship" (Chew, 2012).

Pejorative statements such as Mr. Cook's notwithstanding, since 1970's the USA has lost 80 million jobs of all types (high tech and otherwise). Today an estimated $77 \%$ of all jobs lost over the decades have gone to China. The current national talking points as it relate to the loss of full employment in the USA, is the failure of the American educational system to educate a skilled work force. However, recent data suggests that the America's educational "failure" can only account for $30 \%$ of the increase in inequality nationally (Noah, 2010). Thus based upon these data, educational "failure" accounts for 24 million jobs since the 1970's, the other 56 million jobs that have gone overseas is the product of political economic decisions. Hence, in today's charged political climate over job loss, the social and political elite have turned to educational system as failing to educate a skilled work force as a public placebo. Furthermore, the same elite have added yet another dimension to the school failure equation, the Community College. The American Community College system (we are told) will provide the necessary skills needed to bring back all forms of jobs in the future. Although there is no doubt that a college education in today's market is a source of human capital and a truly noble national goal to have $100 \%$ of the population with a college degree, the reality is that even with the increased need for higher order skills in the "new" post-modern economy fewer than $70 \%$ of the high school graduates go on to college; today's body of research suggest the cause is "Cultural Reproduction of Low Social economic Status (SES) Class Consciences”.

Consequently, as result of the above mention political economic decisions, individuals from low SES backgrounds are faced with two legitimate choices: 1 ) try their chances in a reduced employment market; or 2) enter the community college. The most recent data suggests that for a given 100 high school graduates 35 will go to college. Of this cohort, $65 \%$ will generally find their only collegiate option the community college. Hence, of the 35 college-bound high school graduates (mentioned earlier), 20 will enroll in a community college. Here at worst the majority wills stopout/dropout, and at best a small minority can expect to earn an AA/AAS degree. There is good evidence that Community College students' inability to perform well academically centers around social class. According to Bourdieu and Passeron social class is an important indicator of cultural capital for the school setting (Bourdieu \& Passeron, 1977). Therefore, distinctive cultural knowledge is transmitted by families of each social class. Children of the poor/working class inherit substantially different cultural knowledge, skills, norms, styles of dress and linguistic abilities than children of those within the educated middle class (it is estimated that a middle class child learns 25,000 more words than their low SES contemporary). This concept is referred to as the "Cultural Reproduction of Class Consciences”. The net result statistically is the former will not success in school, and the latter will earn a college degree.

The net result statistically is the former will not success in school, and the latter will earn a college degree. According to Burton R. Clark's (Clark, 1968) suggested that tacit goal of the community college is that of "cooling out". The cooling out hypothesis which 
suggests that students from low SES backgrounds are made to understand that they have academic deficiencies, forcing them to lower their educational aspirations by recognizing that they are unrealistically high; thereby dropping out reproducing low SES class conscience.

\section{Reproduction of Class Conscience}

Generally, it is common knowledge that both working class and middle class parents want their children to succeed in school. However, the social position of each class leads its members to employ different means to this end. Working class parents depend on the teacher and the school to educate their children. On the other hand, the middle class parent tends to actively participate in the supervision and monitoring of his/her child's school achievements. Furthermore, language comparisons of working and low SES families and middle class families suggest that there may be a differential between the language of the home and the language of the schools. According to Basil Bernstein's (Bernstein, 1975) work on language, coding theory, curriculum and the transmission of knowledge is an important interpretation of class, family, school and the failure of Low SES students. Bernstein's concept of code is central to his analysis of the transmission of knowledge. Code refers to a "regulative principle which underlies various message systems, especially curriculum and pedagogy". Curriculum, according to Bernstein, is valid knowledge. Pedagogy acts as the valid transmission of this knowledge and evaluation is the realization of knowledge taught. Both the curriculum and the transmission of knowledge for Bernstein are based in language. According to Bernstein language interpretation determined by class, and is a function of social differences. Furthermore, various functions of language in a given social context have a profound effect on children's social learning. Bernstein establishes a distinction between language usage of the working class or "public language", and the language use of the middle class which he labels "formal language". Furthermore, Public vs. formal language results in the low SES student statistically failing in school; and the middle class student succeeding in school.

\section{The Public Placebo}

As was mentioned earlier, statistically low SES individuals will do poorly within the educational system. However, after World War II there was full employment in the United States which led many uneducated individuals into the middle class mainly through on the job training. Historically, these occupations have acted as an avenue into the middle class by providing good paying wages, health benefits and vacations; with a net positive increase in spin-off jobs. However, based upon national economic decisions since the 1970's which have benefited the profits of the special interest groups (profits earned are the highest in 5 decades with little job creation), the social/political elite find themselves in an social environment which may be malignant to their political careers. Hence, for the purpose of this effort, the definition of the Public Placebo is a sham concept to placate the American public to lessening the political ramifications of decades of poor economic decisions. Thus, in an effort to obfuscate the political pushback by the public, the educational failure fallacy has been created as a public placebo. This public placebo points the finger not only at the American educational system as failing, but at the individual who failed to gained an education (as we saw earlier, Mr. Tim Cook of Apple suggested he could not find an engineer in the USA to file his high tech employment needs and not access to cheap labor). Furthermore, (according to Associated Press in an article published on April 23, 2012) about 1.5 million, or 53.6 percent, of bachelor's degree-holders under the age of 25 last year were underemployed or underemployed (the highest amount in 11 years). College graduates during the last year were more likely to be employed as waiters, waitresses, bartenders and foodservice helpers than as engineers, physicists, chemists and mathematicians combined. They were more likely employed in office-related jobs such as receptionist or payroll clerk than in all computer occupations. Moreover, they are more likely to be employed as cashiers, retail clerks and customer representatives than engineers (Peralta, 2012).

The shocking fact is that young college graduates are heavily represented in jobs that require a high school diploma or less. Hence, the argument that the American educational system is not providing a skilled workforce is simple a public placebo which has acted as an obfuscation of the decades of national economic and trade decisions favoring special interests, stunting the growth of the American people. Further compounding the educational fallacy is the constant exposure to a contrived need for unnecessary technology. Most parents now believe that their children must learn all the apps, social networking, I-phones, E-payments, computer assisted learning, teaching technology, mobile devices, and electric text books. The dialectic twist in this contrived technical revolution is that the children are learning to accept, and live with chronic unemployment. A case in point is the social network Face book. Face book today is worth billions of dollars, but has only created 1200 jobs worldwide. By contrast, that same net worth in the USA auto industry would create hundreds of thousands of high paying auto industry position, and equal as many spin-off support positions (Gerardi, 2012).

\section{The Social Context of Educational Systems: Conclusion}

Although statistically it is true that the United States ranks $9^{\text {th }}$ in Mathematical outcomes internationally (based upon the 2011 8th grade math exam outcomes), however, the statistical method used in the comparison of such different school systems (USA vs. international systems) is structurally misleading, and functionally inaccurate. A case in point is the data submitted by the Singapore and South Korea's educational systems.

\section{Singapore}

Singapore was the top performing educational system for 8th grade mathematical outcomes in 2011. So then what is behind such an impressive achievement? Are the Singapore students smarter than their American counter-parts? Are the Singapore Educators more professional than their American counter-parts? Is Singapore's educational system a mass public education system as their American counter-part? Is an academic education in Singapore a right as it is in the American counter-part? Is Singapore mono-linguistic country unlike its American Counterpart (in New York City there is 110 language dialects spoken)? Is Singapore ethnically and racially diverse as its American counter-part? Is Singapore a Mechanical Collective Conscience 
(Durkheim's concept of a society which everyone has the same values, norms and attitudes) or an Organic Collective Conscience as its American counter-part (Durkheim's concept of a Collective Consciences with different values, norms and attitude)?

The short answer to this query is no. The fact is that Singapore's educational success is based in the results of the Primary School Leaving Examination (PSLE) (this exam is taken by students in the 6th grade). Students are placed in different educational tracks or ability grouping, the Special, and Express, Normal Academic, and Normal Technical tracts; hence it is a grade based sample. The difference between Special and Express is that Special students take Higher Mother Tongue' (available for Chinese, Malay and Tamil only) instead of just Mother Tongue. Thus there is a continuing manifest educational filtering system based upon "ability grouping", an old pedagogical method abandoned decades ago in the United States. By contrast, the United States is a mass public free educational system in which the education of its' citizens' is a right not a privilege. Thus, the data submitted by Singapore (based on the results of the PSLE) are a grade based sample, this grade based sample is being compared to the American system. Furthermore, the American Educational system entitles everyone a fair and equal education, regardless of social, political, physical or learning disabilities, thus is not a grade based population. Hence, it is the position of this effort that a fair analysis of the top academic intuitions in the America system would produce outstanding academic outcomes

\section{South Korea}

Another educational obstacle found in the American system (as we saw earlier) is the parent's social background with a bias toward not participating in their child's education. In South Korea for example, (the second top performing school system in 8th grade mathematic for 2011) high school graduates who do not gain admission to the top universities, spend year after year in tutoring sessions (hagwons) to improve their scores on university admissions exams. The basis for this fetish is the South Korean parents' culture which demands a strong educational work ethic of their children. There are many reports that point to legions of grade school children sleeping in class because they were up all night studying and doing homework. Hence, the comparison of the top performing educational systems internationally (Singapore/South Korea) to the USA is akin to comparing the Theory of Evolution to that of Intellectual Design. Both theories attempt to explain life on earth, however the latter has no scientific data to support its' claims. Likewise, comparing the USA with international educational systems (which are not mass public systems) is structurally misleading, again due to the fact that America's educational system simple does not have a manifest education filter (in fact the current educational philosophy is "NO CHILD LEFT BEHIND”), and does not submit grade based samples. Mark Twin was once quoted as saying "there are three types of lies": lies, damn lies and statistics".

To sum up, this effort suggested that since the 1970's there has been: 1) millions of jobs gone overseas to accommodate the profits of special interest groups; 2) this has lead to millions of underemployed and/or unemployed workers destroying the Middle class and the hope for middle class aspirations; 3) the community college ability to provide the necessary skills to bring back millions of jobs is a fantasy: 4) a national goal of 100 percent of Americans earning a college degree is based in utopian ideals; and 5) American's education system failure is simply a public placebo in the creation of a smokescreen hiding decades of economic decisions which have destroyed the American Dream. In July 2012 Dr. Stephen Krashen Ph.D. Professor Emeritus of Learning and Instruction at the University of Southern California spoke at a national conference held at Fordham University conference in New York City saying “There’s nothing wrong with our schools...there is no crisis,”...it is 100 percent manufactured...the whole thing is a hoax". Indeed, this effort agrees with Dr. Krashen's "hoax” criticism. This effort further views the "hoax" as a contrived response to decades of national economic and trade policies which has failed the American people. Moreover, the America's educational system has been used as a pawn, as a public placebo in the obfuscation of decades economic and trade policies which have benefited the "special interests" groups.

\section{REFERENCES}

Bernstein, B. (1975). Class, codes and control. New York, NY: Rutledge Publishing.

Bourdieu, P., \& Passeron, J. C. (1977) Reproduction in education, society and culture. London: Sage Publications.

Chew, K. (2012). 1 in 2 college graduates unemployed or underemployed, associated press analysis. New York, NY: Associated press analysis publication.

Clark, B. (1968). The cooling out function of higher education. The American Journal of Sociology, 2.

Gerardi, S. (2012). Social change, mode of-production and the tendency toward capital concentration. Sociology Mind, 2.

Krashen, S. (2012). To improve schools, fight poverty. Lecture at Fordham University, Bronx, New York.

Noah, T. (2010). Back-of-the-envelope. New York, NY: Slate Magazine.

Peralta, E. (2012). Half of recent college grads are jobless or underemployed. New York, NY: Associated press analysis publication. 